\title{
Distribution, habitat affinities and phenology of the Micrargus herbigradus-species group (Araneae: Linyphiidae) in Poland
}

\author{
Konrad Wiśniewski ${ }^{1}$ (D) Robert Rozwałka ${ }^{2} \cdot$ Wanda Wesołowska $^{3}$
}

Received: 17 July 2017 / Accepted: 29 January 2018 / Published online: 19 March 2018

(C) The Author(s) 2018

\begin{abstract}
We review the known information on the distribution and habitat affinities of the Micrargus herbigradus-species group in Poland. The analysis is based on a thorough literature survey, our own materials, and verification of some older collections. We give new diagnostic drawings and review the characters that are useful in identification of species within the group. Three species are present in Poland: M. herbigradus (Blackwall, 1854), M. apertus (O.-P. Cambridge, 1870) and M. georgescuae Millidge, 1976. The latter is recorded for the first time in the country, and we add numerous new localities for the two former species. Micrargus herbigradus is common and widespread in Poland, living in various habitats, with only a slight preference to forests. In contrast, $M$. apertus is widely distributed but rarely found, while its affinity to forests is the highest within the group. The records of this species are most numerous in lowland forests (up to c. $300 \mathrm{~m}$ a.s.l), but it can also be found at higher altitudes. M. georgescuae is found only in montane habitats, both in the Sudetes and the Carpathian Mountains, from above $650 \mathrm{~m}$ a.s.l. The adults of all three species occur the whole year round, but seem to be most abundant in May and June.
\end{abstract}

Keywords Micrargus apertus $\cdot$ Micrargus georgescuae $\cdot$ Micrargus herbigradus $\cdot$ Central Europe $\cdot$ New records $\cdot$ Mountains

\section{Introduction}

The Micrargus herbigradus-group contains four Central European species: M. alpinus Rëlys and Weiss, 1997,

Electronic supplementary material The online version of this article (https://doi.org/10.2478/s11756-018-0026-5) contains supplementary material, which is available to authorized users.

Konrad Wiśniewski

konwisniew@gmail.com

Robert Rozwałka

arachnologia@wp.pl

Wanda Wesołowska

helena.wesolowska@uwr.edu.pl

1 Department of Zoology and Animal Physiology, Institute of Biology and Environmental Protection, Faculty of Mathematics and Natural Sciences, Pomeranian University in Słupsk, Arciszewskiego 22b, 76-200 Słupsk, Poland

2 Department of Zoology, Faculty of Biology and Biotechnology, Maria Curie Skłodowska University, Akademicka 19, 20-033 Lublin, Poland

3 Department of Biodiversity and Evolutionary Taxonomy, University of Wrocław, Przybyszewskiego 65, 51-148 Wrocław, Poland
M. apertus (O.-P. Cambridge, 1870), M. georgescuae Millidge, 1976 and M. herbigradus (Blackwall, 1854). Two species from this group, M. apertus and M. herbigradus, have been recorded in Poland. Here we add one more species to the list of the Polish fauna, i.e. M. georgescuae. Micrargus subaequalis (Westring, 1851), which is also present in Poland, belongs to a separate species group.

The species group discussed here was revised by Millidge (1976), and subsequently one further species was described from the Alps by Rëlys and Weiss (1997). Due to difficulties in the identification of Micragus species, their actual distribution in Poland was uncertain. Some authors suggested the presence of more than two herbigradus-group members (Starega and Kupryjanowicz 1996), or the presence of some new species (Starega 2003a), but they did not make final conclusions about the specimens' identity. Since the species are difficult to identify we summarize all the features that are useful for their determination.

Although the biology of this species group is fairly well described in the literature, there is no thorough analysis of the data from Poland. Some of the published remarks on their ecology might have been simplifications. Thus, we summarize the features for accurate species identification, revise the data on the distribution of these species in the country, 
referring both to published information and our own findings, and analyze their characteristic habitats and phenology. Furthermore, we review the ambiguous data from previous publications.

\section{Methods}

We gathered information from different studies, both published and unpublished. The published data are listed in the results, for which some of the previous records were verified (Starega and Kupryjanowicz 1996; Staręga 2003a). In total, 97 articles were used for summarizing information on the distribution, habitat preferences and phenology of the herbigradus-group in Poland. Additionally, we included unpublished records that emanate from our own research in the analysis, of which all the specimens were identified by us. The detailed list of new, unpublished records is attached as supplementary electronic material (Online Resource 1: Tables S1S4). The analysis of the distribution is based on research utilizing diverse methods of sampling material, i.e. pitfall traps, sweep net, sieving or direct search. The intensity of research in different parts of the country was decisively uneven, thus some results might be biased.

For the analysis of the altitudinal distribution and habitat preferences, we used the single sampling plots as units and did not consider the numbers of recorded specimens. When different habitats were investigated in a particular study - even if they were situated very close to each other - we counted them as separate plots. Based on literature, we assigned each plot to an altitudinal interval at $100 \mathrm{~m}$ resolution, i.e. $0-100,100$ $200 \mathrm{~m}$ a.s.l., etc. This resolution still allowed us to draw some meaningful conclusions, but it was the highest resolution that we could apply to data from the literature.

Furthermore, the properties of the habitats in each plot were studied. In the first step of the analysis we divided the habitats into open or forested. The second division was based on the humidity. We sorted habitats according to their humidity, with five successive levels. The attribution of each habitat to a humidity level does not refer to the exact place or time (which could not be verified), but to the typical features of a habitat type, e.g. all lowland alder forests or different mire types were recognized as 'very moist'. The data in the literature were obviously of different quality or credibility, thus selected records were excluded from some counts. The exact number of records used in each analysis is given in the results.

For the analysis of phenology as a unit we have used a single record of a species in one plot, per year (i.e. records from the same plot and date coming from two different years were counted separately). We have divided the records into those coming from the first half of each month (1st-15th) and those from the second half (16th-end). For data from pitfall traps we have assigned the record to the respective period by taking the middle date of the trap exposure time.

\section{Results}

\section{Distinguishing species}

Males of the Micrargus herbigradus-group can be identified by comparing their embolus, size and form of the adjacent lamellae, and the shape of the process (apical spine) that accompanies the embolus. Micrargus georgescuae has a conspicuously wide basal part of the embolus (Figs. 4, 11), while that of M. apertus and M. herbigradus is thin (Figs. 17 and 19, respectively). The apical spine of the palp is slightly sinuous, with a truncated tip in M. herbigradus (Fig. 20), whereas $M$. apertus and $M$. georgescuae differ in having this process smooth apically (Figs. 18 and 12). This spine is shorter and straight in M. apertus (Fig. 18), but clearly longer and slightly bent in M. georgescuae (Fig. 12). The lamellae accompanying

Table 1 Morphological characters useful in identification the Micrargus herbigradus-species group members

\begin{tabular}{|c|c|c|c|}
\hline Character & $\begin{array}{l}\text { herbigradus } \\
\text { (Figs 19-20, 28-30) }\end{array}$ & $\begin{array}{l}\text { apertus } \\
\text { (Figs 16-18, 25-27) }\end{array}$ & $\begin{array}{l}\text { georgescuae } \\
\text { (Figs } 1-15,21-24)\end{array}$ \\
\hline Embolus basally & thin & thin & wide \\
\hline Apical spine & short, sinusoid & short, straight & long, bent \\
\hline Tip of apical spine & truncated & pointed & pointed \\
\hline Lamella & $\begin{array}{l}\text { robust, partially surrounding } \\
\text { spine }\end{array}$ & large, rhomboid & small, triangular \\
\hline $\begin{array}{l}\text { Inlet part of seminal ducts, } \\
\text { before the loop }\end{array}$ & short, straight & long, curved & short, straight \\
\hline Anterior loop of seminal duct & $\begin{array}{l}\text { loose, large, distant from } \\
\text { spermatheca }\end{array}$ & $\begin{array}{l}\text { narrow, small, close } \\
\text { to spermatheca, }\end{array}$ & $\begin{array}{c}\text { narrow, small, close } \\
\text { to spermatheca }\end{array}$ \\
\hline $\begin{array}{l}\text { Distal part of seminal duct, } \\
\text { behind the loop }\end{array}$ & long & short & short \\
\hline
\end{tabular}


Figs 1-7 Micrargus georgescuae Millidge, 1976. 1. General appearance of male; 2 . General appearance of female; 3 . Palpal organ, prolateral view; 4. Ditto, ventral view; 5. Ditto, ventroretrolateral view; 6. Ditto, retrolateral view; 7. epigyne
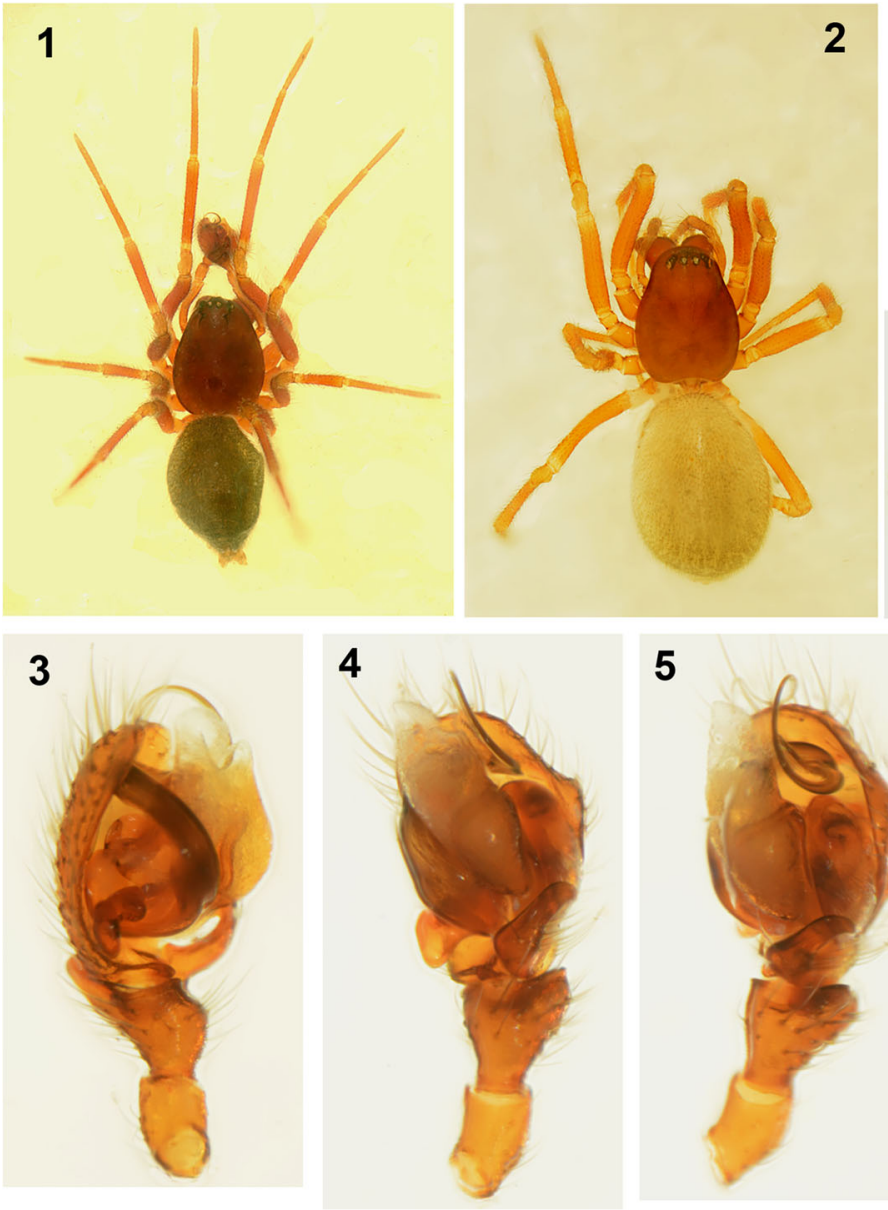

5
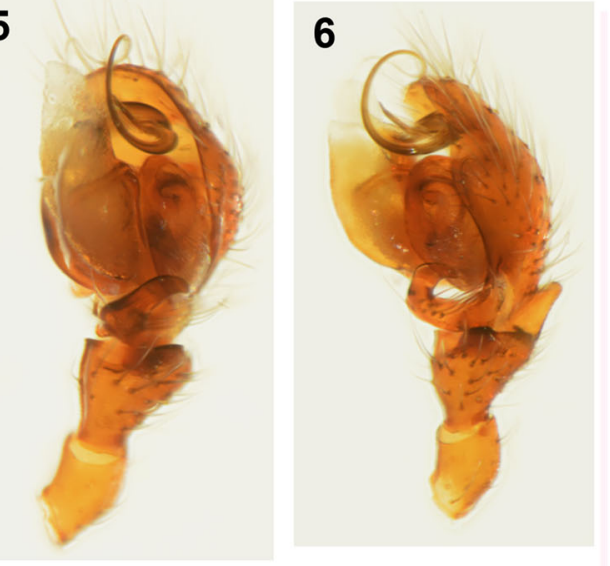

the process are much smaller in M. georgescuae (Fig. 15) compared to $M$. apertus, and have a distinctly different shape.

The females can be identified by the arrangement of the seminal ducts, a structure seen on the inner side of the epigyne after dissecting it. We suggest not to try distinguishing species without dissecting this structure, although there might be some interspecific differences (Figs. 21, 25, 28). The seminal ducts of $M$. herbigradus form very distinctive long, wide and bent coils in the anterior part of the epigyne, relatively far from the spermathecae (Figs. 29, 30), whereas in M. georgescuae the ducts form a small narrow loop (Figs. 23, 24). The ducts of M. apertus have a much more complex structure: the first loop extends clearly in the anterior part of the epigyne, and subsequently forms a posterior coil (Figs. 26, 27). We summarize the features useful in species identification in Table 1.

The species differ also in the microsculpture of the stridulatory organs, which was shown by Rëlys and Weiss (1997). The other feature that distinguishes the herbigradus-group species is their size, $M$. apertus being the largest one, as mentioned by Millidge (1976). However, these characters are of little use in identifying spiders, unless one has all of the species available for comparison.

\section{New localities}

This study represents the first report of $M$. georgescuae in Poland. In total, 126 individuals (63 males and 63 females) were collected in several mountain ranges of the Carpathians the Beskid Wyspowy, the Tatra Mountains, the Gorce (all in SCentral Poland); in the Orawa-Nowy Targ Basin, at high altitudes; and in the Sudetes - the Stołowe Mountains and the Giant Mountains (SW Poland; Fig. 31).

The specimens from the Gorce come from the study by Starega and Kupryjanowicz (1996); most of this material belonged to $M$. georgescuae (Online Resource 1: Table S2). The species was present solely in the mountains, thus its range is restricted to the southern part of the country. It is not widespread, but in places where it lives, $M$. georgescuae may be quite numerous (Online Resource 1: Table S3). When one considers its broader European range, it was found in several major mountain ranges of Central Europe (see the Discussion).

Micrargus apertus is reported from five new localities in different parts of the country; it has already been recorded from 16 UTM (Universal Transverse Mercator) 
Figs 8-15 Micrargus georgescuae Millidge, 1976, male. 8. Cheliceral dentition; 9. Palpal organ, prolateral view; 10 . Ditto, ventroprolateral view; 11. Ditto, ventral view; 12. Ditto, ventroretrolateral view; 13. Ditto, retrolateral view; 14. Ditto, dorsal view; 15. embolic part. Scales: $0.1 \mathrm{~mm}(9-14), 0.2 \mathrm{~mm}(8), \mathrm{eb}$ embolic base, as - apical spine, la - lamella
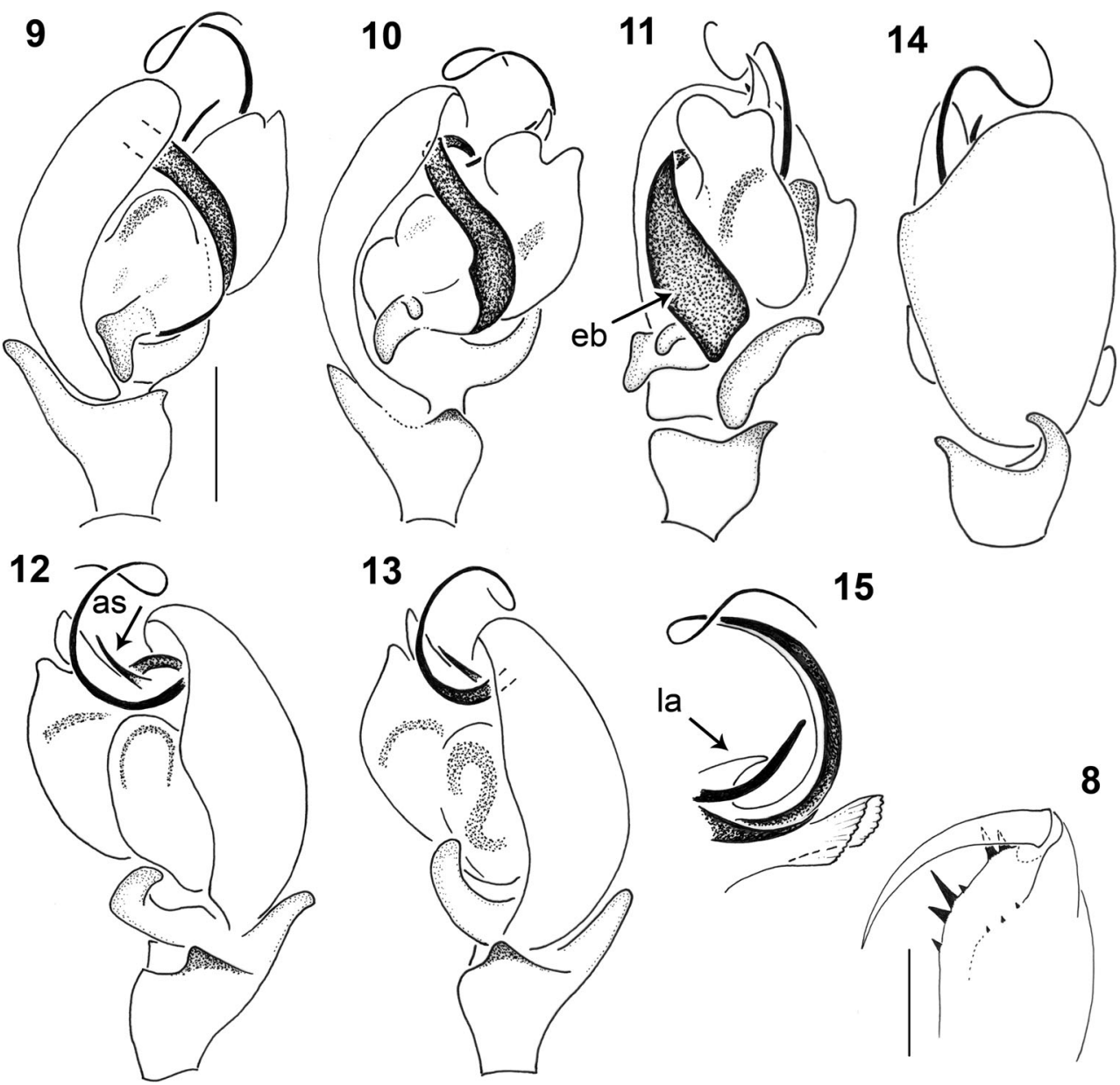

15

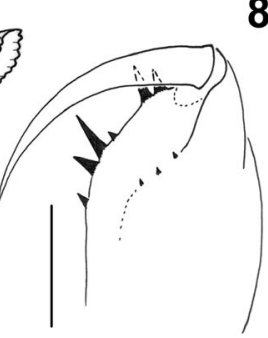

squares previously. The localities are scattered around the country, from the lowlands to the mountains (Fig. 32, Online Resource 1: Table S1).

Micrargus herbigradus is extremely common, and the relatively large number of published and newly added localities from Poland does not totally depict its true distribution, which is surely much broader. In addition to the 175 UTM squares that it has been reported from previously, we add 40 points to the grid. We confirm its presence in eight localities. In total, the species has now been recorded from 215 UTM grid squares (Fig. 33; Online Resource 1: Table S4).

\section{Altitudinal distribution, habitats and phenology}

The altitudinal distribution of the three species overlaps (Figs. 34-36). The only species with a clear preference to the mountains is M. georgescuae (Fig. 35), which in Poland occurs from about $670 \mathrm{~m}$ a.s.l., evenly distributed up to 1850 m a.s.l. (Online Resource 1: Tables S2, S3). Micrargus apertus and M. herbigradus were mostly found in Poland between 100 and $300 \mathrm{~m}$ a.s.l.. However, both of them appear in the mountains up to the subalpine level, and they sometimes cohabited with M. georgescuae.
All of the species show some preference towards forests compared to open habitats (Figs. 37-39), although they are not considered to be typical forest-dwellers. The percentage of the forested plots occupied by M. apertus was the highest of the three species, suggesting a stronger association with this habitat type (Fig. 37).

Micrargus apertus and M. georgescuae occur more frequently in humid habitats (Figs. 40, 41). The latter species is typical for the mountains, which - in Poland - have a cooler and more humid climate than in the other parts of the country. Micrargus herbigradus is present in all the habitat types (Fig. 42), from xerothermic, extremely dry stands, to periodically flooded forests and the mires. However, the majority of records come from stands of moderate moisture. The habitats of $M$. apertus are also diverse, including former sand quarries, crops, different forest types, caves and a subalpine bog. The diversity of $M$. georgescuae's habitats is also conspicuous, i.e. montane spruce, alder or beech forests, dwarf pine shrubs, meadows, mountainous grasslands or different mire types.

The adults of the three species are present for most of year. Micrargus apertus was recorded from April to November. The data on its occurrence are scarce, but evenly distributed within the period (Fig. 43). The adults of M. georgescuae have 
Figs. 16-20 Micrargus apertus (O.-P. Cambridge, 1870) and Micrargus herbigradus (Blackwall, 1854), males. 16. M. apertus, palpal organ, ventral view; 17. Ditto, ventroretrolateral view; 18. Ditto, retrolateral view; 19. M. herbigradus, palpal organ, ventral view; 20. Ditto, retrolateral view. Scale: $0.1 \mathrm{~mm}$

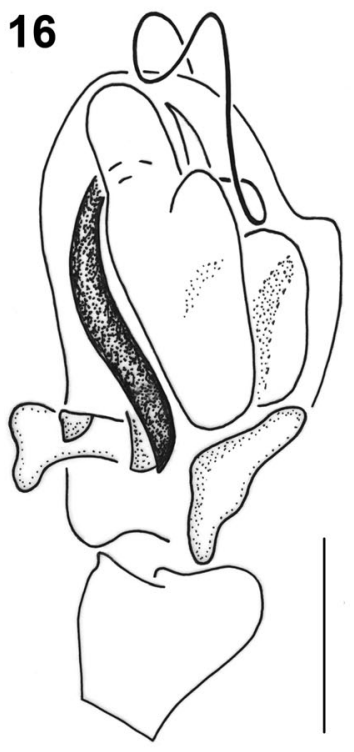

17

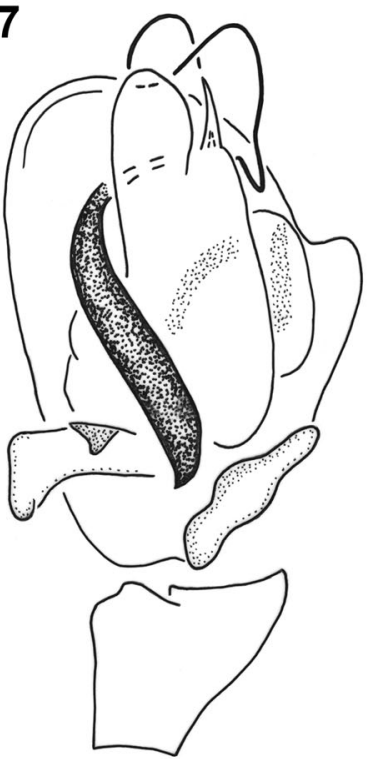

19

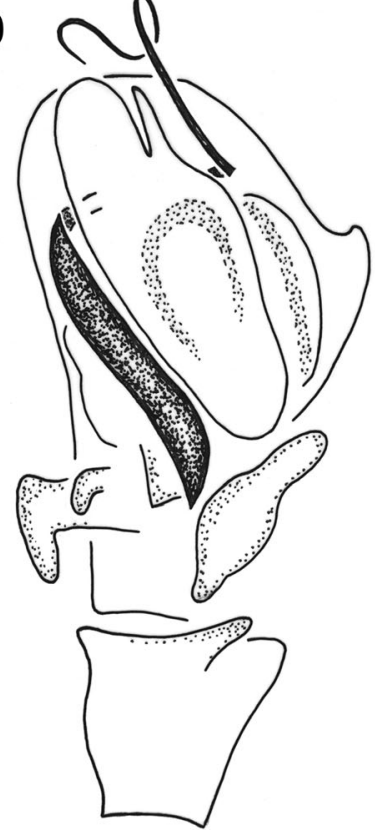

18

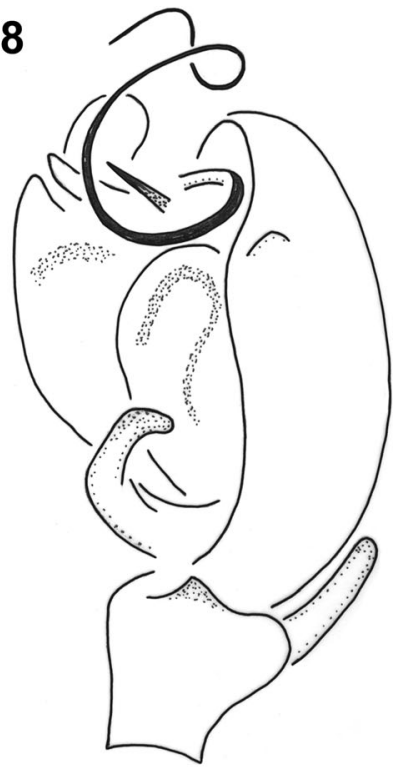

20

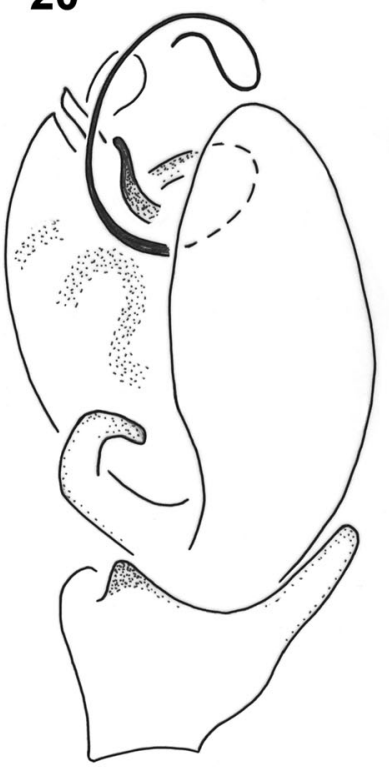

two activity peaks, in late spring and early autumn (Fig. 44). The temporal distribution of M. herbigradus spans the whole year, with the highest peak in May and June (Fig. 45).

\section{Discussion}

Our data update information on the distribution of the $M$. herbigradus-species group in Central Europe. Micrargus georgescuae is newly recorded from Poland, where it occurs in the mountains and is locally abundant. It inhabits several European mountain ranges, as the Alps (Thaler 1978; Maurer and Walter 1980; Rëlys and Weiss
1997; Höfer et al. 2010), but also various lower massifs in Germany (Arachnologische Gesellschaft 2017), Czechia (Buchar and Růžička 2002; The Czech Society of Arachnology 2017) and Slovakia (Franc 2002; Svatoň and Kovalčík 2006). It is also present in some other mountain ranges of the Carpathians (Gajdoš et al. 2014), namely in the Ukrainian Chornohora (Hirna et al. 2016) and in Romania (Georgescu 1971; Millidge 1976; Urák and Samu 2008). The species has already been recorded in the mountains close to the study sites referred to in the text, such as the Ore Mountains (Růžička and Hajer 2000), the Hrubý Jeseník (Majkus 2006) or the Great Fatra (Franc 2002), but also in the same mountain ranges, 
Figs. 21-24 Micrargus georgescuae Millidge, 1976, female. 21. Epigyne, ventral view; 22. Epigyne, lateral view; 23. Spermathecae, ventral view; 24. Spermathecae, dorsal view. Scale: $0.1 \mathrm{~mm}$
21

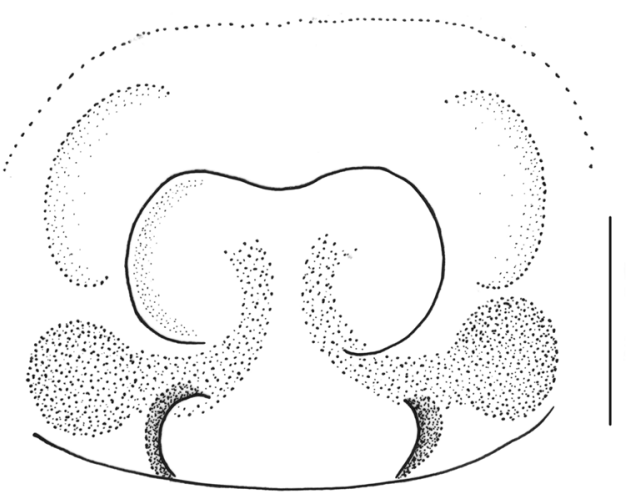

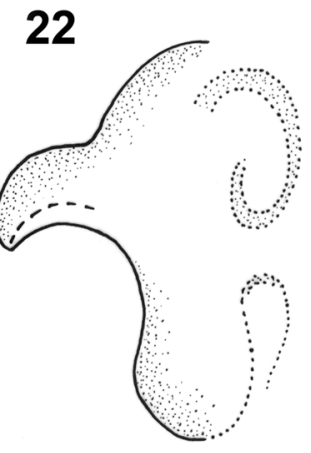

23

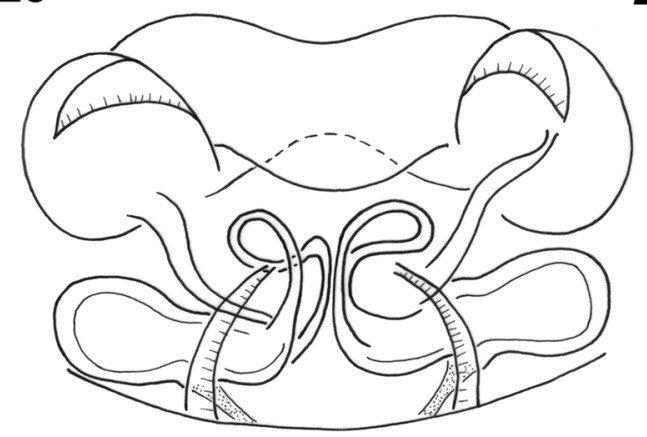

24

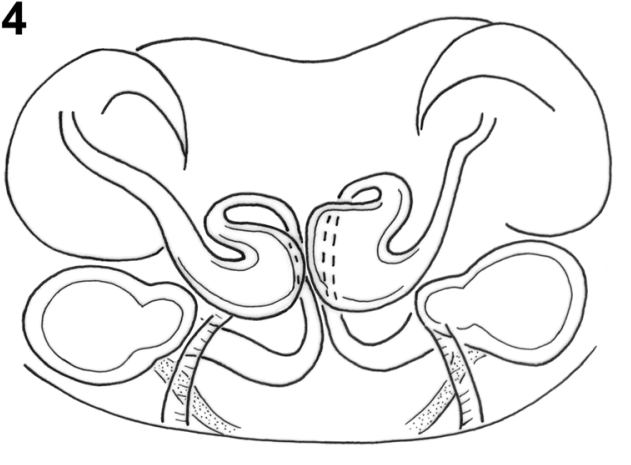

i.e. the Giant Mountains (Kůrka and Vaněk 2001; Kůrka and Vaněk 2009; Materna et al. 2010), the Central Sudetes (Buchar and Rủžička 2002) and the Tatra Mountains (Svatoň and Kovalčík 2006). Micrargus georgescuae was not found in the mountains of SE Poland (the Bieszczady and the Eastern Beskidy), even though these ranges have been very intensively surveyed recently. It is also absent in the Slovak part of this mountain massif (Svatoň et al. 2003 only list M. herbigradus). Similarly,
M. georgescuae was not found in the Izera Mountains (the Western Sudetes) that are close to the other mountain ranges where the species occurs. These mountains have also been intensively surveyed during the last decade.

Micrargus apertus is a species that is rarely found. Considering the arrangement of its localities in other countries, e.g. in Germany (Arachnologische Gesellschaft 2017) or the Czech Republic (Czech Society of Arachnology 2017), and the uneven, apparently disordered
Figs 25-30 Micrargus apertus (O.-P. Cambridge, 1870) and Micrargus herbigradus (Blackwall, 1854), females. 25. M. apertus, epigyne; 26. Ditto, spermathecae, ventral view; 27. Ditto, spermathecae, dorsal view; 28. Micrargus herbigradus, epigyne; 29. Ditto, spermathecae, ventral view; 30 . Ditto, spermathecae, dorsal view. Scale: $0.1 \mathrm{~mm}$
25

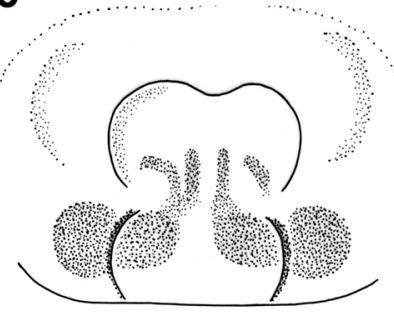

28

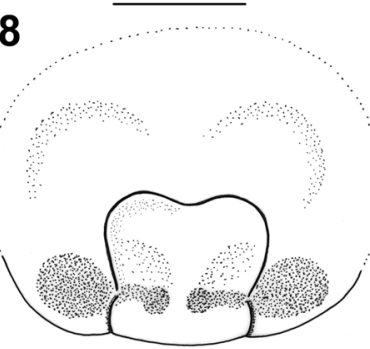

26

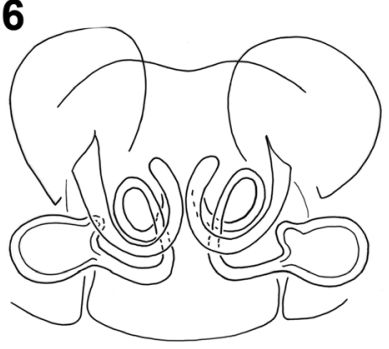

29

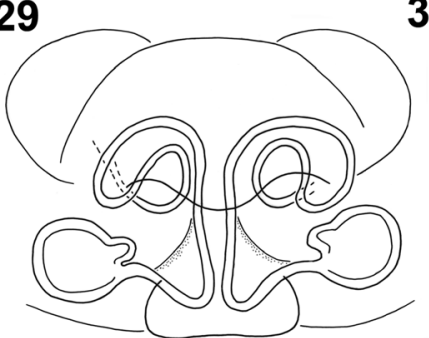

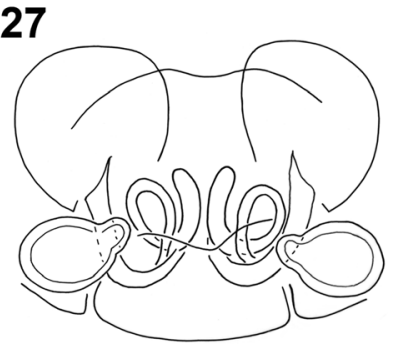

30

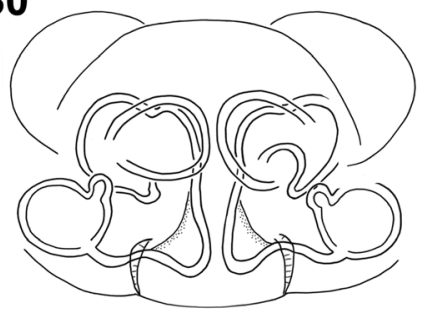




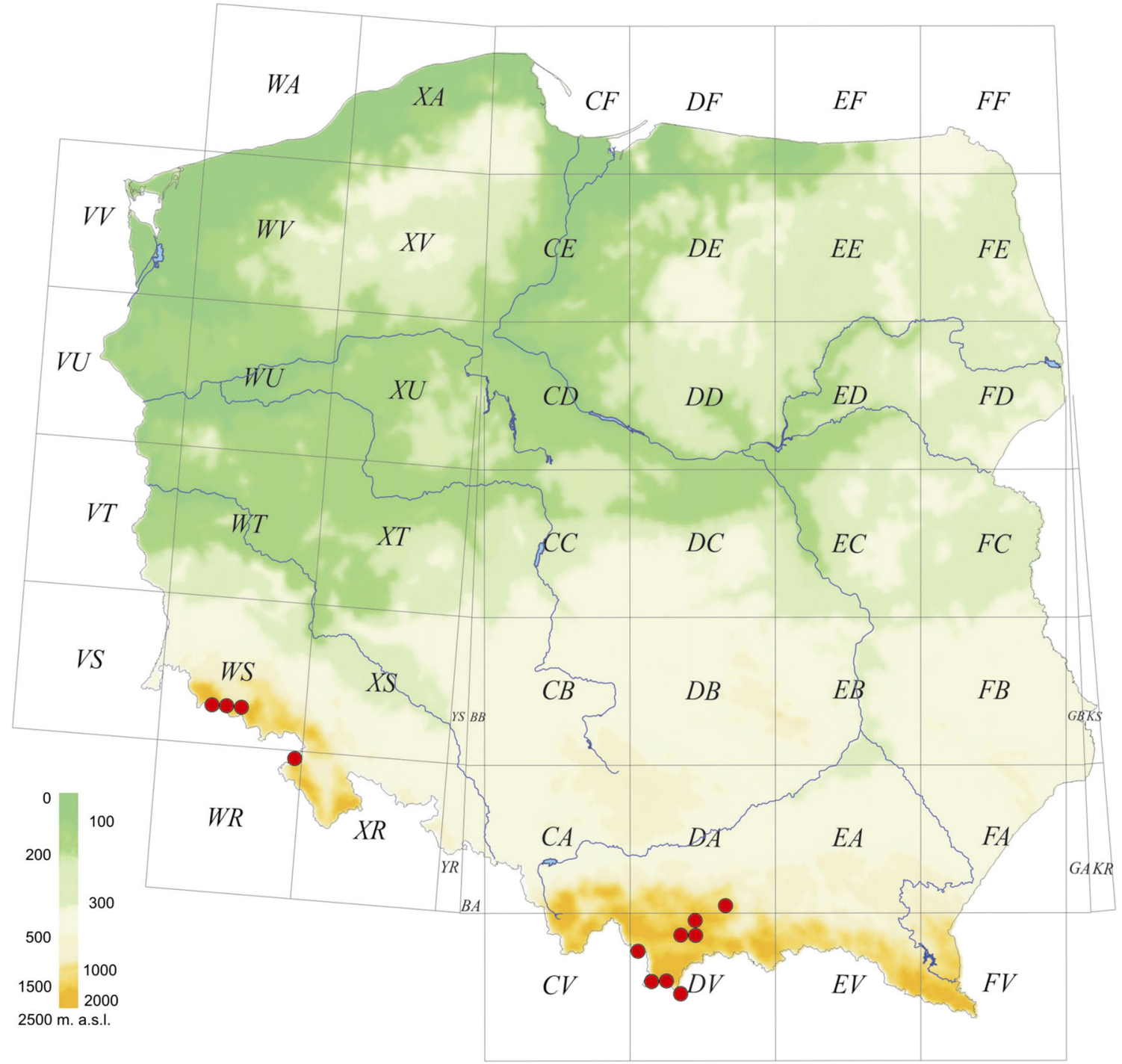

Fig. 31 Distribution of Micrargus georgescuae in Poland. References: Starega and Kupryjanowicz (1996): as a new species related to Micrargus georgescuae (only part of specimens). The red dots in all maps refer to our own findings or the material verified by us

distribution in Poland, it might be expected that M. apertus is much more widespread, although uncommon. On the British Islands it seems to be more common in the northern parts (British Arachnological Society 2017). The species might often have been misidentified. Micrargus herbigradus is widespread and common almost throughout Europe (Nentwig et al. 2017), and the presented distribution map of Poland is surely incomplete.

The results on the altitudinal preferences of the three species in Poland might be biased both by the geography of the country, with its area situated mostly at the altitudes between 0 and $300 \mathrm{~m}$ a.s.1., and by the way the arachnologists have chosen investigated regions. There are numerous gaps, i.e. regions that have received little or no interest historically (e.g. the Western Pomerania and some parts of Central Poland). There is a clear affinity of
M. georgescuae towards mountainous regions, with the lowest localities situated approximately at $650 \mathrm{~m}$ a.s.l. A similar pattern might be observed in Germany, where the species clearly prefers mountains (Arachnologische Gesellschaft 2017). However, in the Czech Republic the spider was found at lower altitudes, from $350 \mathrm{~m}$ a.s.l., with a peak around 400-600 m (Buchar and Růžička 2002). It might be linked to abundance of montane areas in this country and the availability of specific habitats such as wetlands or stone gorges, with which the species might by partly associated there (Buchar and Růžička 2002). Altitudinal ranges of the species from the herbigradus-group overlap both in Poland, in the Czech Republic (Buchar and Růžička 2002) and - for example - the Alps (Muster and Leipold 2001). In the latter case the authors mentioned some separation of the habitats within the group 


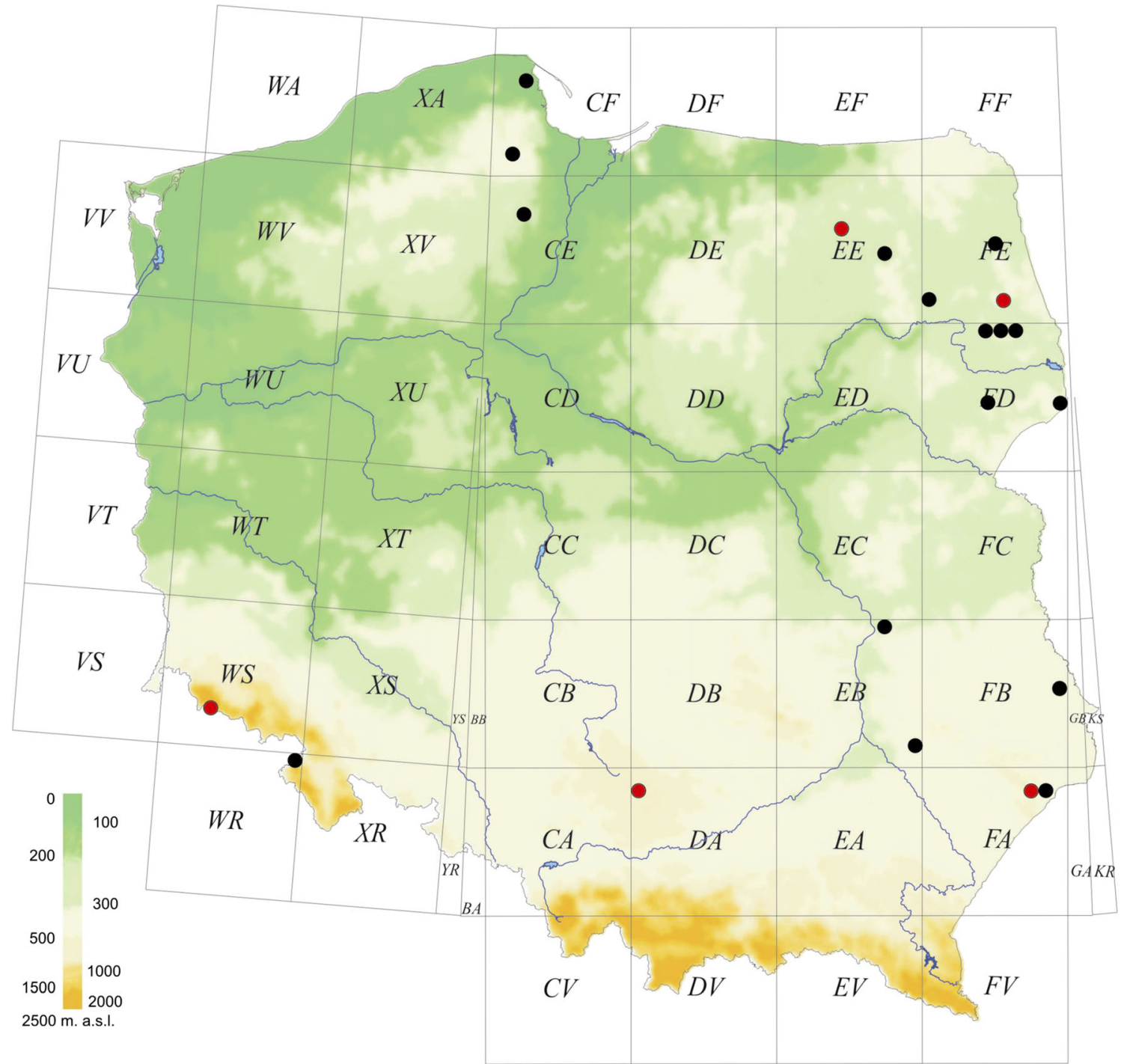

Fig. 32 Distribution of Micrargus apertus in Poland. References: Starega (1996a), Staręga and Stankiewicz (1996), Chyży and Staręga (1997), Staręga (2003a), Rozwałka (2004), Kupryjanowicz (2005), Stańska
(2005, 2007), Rozwałka (2009, 2010a), Hajdamowicz et al. (2016). The red dots refer to our own findings, the black dots to the data from the literature (additionally with $M$. alpinus), although sometimes the species were observed together (Muster and Leipold 2001). We have also observed their cohabitation in some localities. Micrargus is therefore an example of the genera that undergo high diversification in Europe, with a few examples of altitudinal vicariants, such as M. alpinus or M. georgescuae. Care should be taken in investigating material from the mountains, because some other new forms might be expected in the other massifs.

Micrargus herbigradus was sometimes described as a silvicolous species (Kupryjanowicz 2008; Nentwig et al. 2017), only sporadically occurring in open habitats (Buchar and Růžička 2002). However, this might be a broad simplification, or its preferences are geographically changeable, according to - for instance - the availability of specific habitat types in the region. In Poland and some other European countries (Hänggi et al. 1995) $M$. herbigradus is a common, eurytopic species, with no specific habitat preference. Generally, it is commoner in humid habitats and has no preference towards open or shaded places (Entling et al. 2007). In Poland, $M$. apertus seems to have an affinity towards shaded habitats. However, the total number of its records is considerably low, which may have influenced the results. Micrargus georgescuae does not have special habitat preferences, apart from living in cool and humid climates of the mountains.

Micrargus herbigradus also inhabits some specific microhabitats (Online Resource 1: Table S4), as we have observed this species in the (slightly destroyed) nest of the ant Lasius 


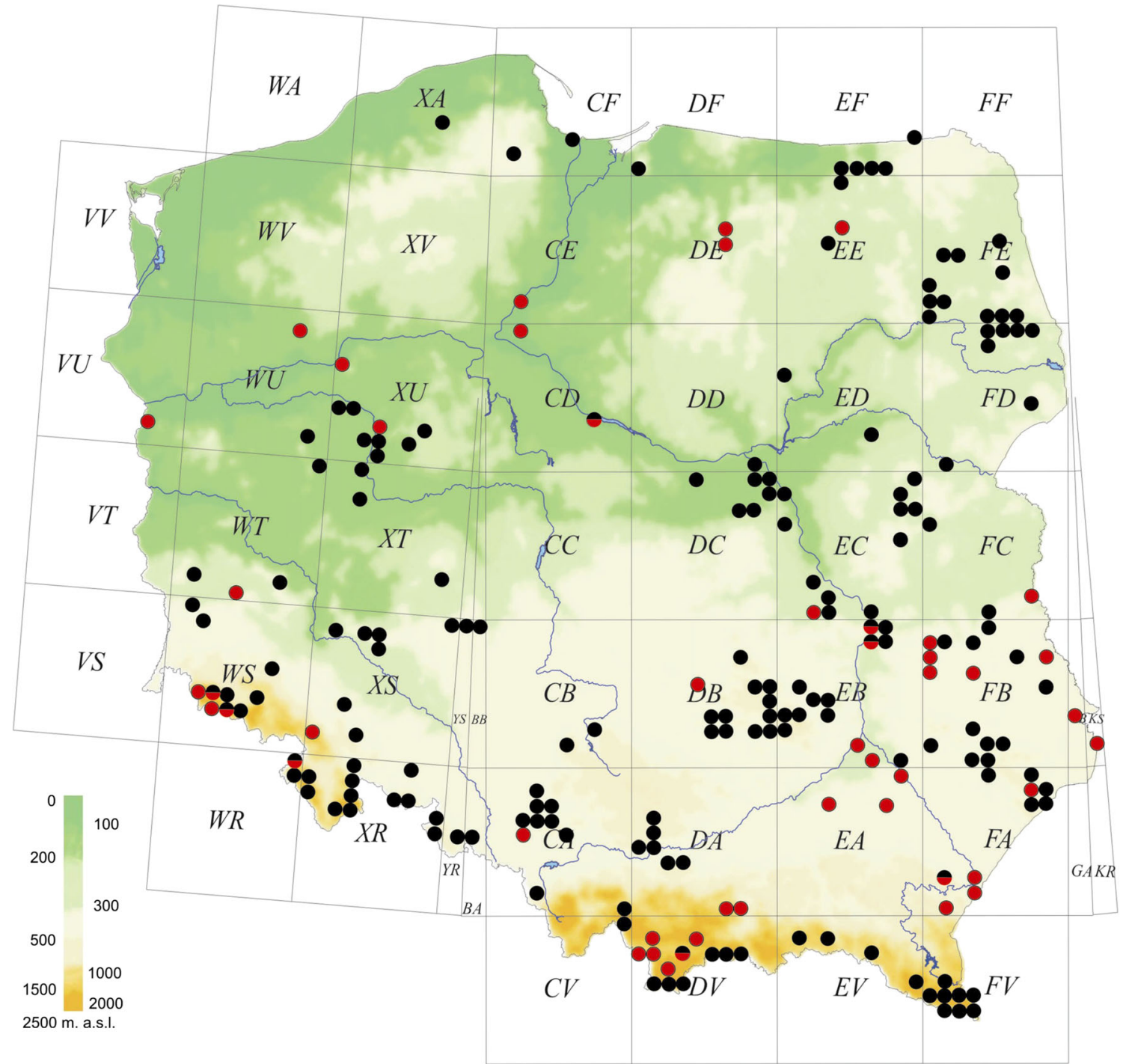

Fig. 33 Distribution of Micrargus herbigradus in Poland. References: Nowicki (1874), Kulczyński (1876, 1881), Dahl (1902), Schenkel (1929), Kajak (1960), Łuczak (1960), Pilawski (1962), SanockaWołoszyn (1964), Pilawski (1965), Bednarz and Czajka (1966), Pilawski (1966a, b), Starega (1966), Pilawski (1967), Pilawski (1970), Prószyński and Starega (1971), Starega (1971, 1972), Deltshev and Kajak (1974), Dziabaszewski (1974), Staręga (1974), Woźny (1975a, b), Czajka (1976), Czajka and Goos (1976), Staręga (1976), Woźny (1976), Staręga (1978), Jędryczkowski and Staręga (1980), Krzyżanowska et al. (1981), Puszkar (1981), Sanocka-Wołoszynowa (1981), Czajka and Kornalewicz (1982), Krzyżanowska (1982), Starega (1984), Woźny (1985), Staręga (1988), Tomek (1988), Woźny et al. (1988), Dziabaszewski (1989), Dziabaszewski et al. (1989), Staręga (1989), Dziabaszewski (1991), Woźny (1992), Czajka and Domin (1993), Wojtaczka and Woźny (1993), Łęgowski (1995), Staręga (1995), Sielicki and Staręga (1996),

fuliginosus in a tree. It is also a common cavedweller (Sanocka-Wołoszynowa 1964, SanockaWołoszynowa 1981). The species was observed in the diet of dunnock hatchlings (Prunella modularis) by Tomek (1988).

The results on the phenology of the M. herbigradusspecies group are consistent with those from some other
Starega (1996a, b), Staręga and Stankiewicz (1996), Woźny (1996), Baldy and Woźny (1998), Łuczak and Woźny (1999), Szymkowiak et al. (1999), Rozwałka (2000), Staręga (2000), Woźny and Szymkowiak (2000), Łegowski (2001), Staręga and Kupryjanowicz (2001), Baldy (2002), Wolak (2002), Stańska et al. (2002), Kupryjanowicz (2003), Starega (2003a, b), Kajak and Oleszczuk (2004), Rozwałka (2004), Szymkowiak and Górski (2004), Wolak (2004), Kupryjanowicz (2005), Łegowski (2006), Rozwałka (2006a, b, c), Rozwałka (2007a, b), Rozwałka 2008, Stańska and Łydkowska (2008), Rozwałka and Juszczyński (2009), Rozwałka (2009), Oleszczuk (2010), Rozwałka (2010a, b, c), Rozwałka (2012), Cichocki and Rozwałka (2013), Rozwałka (2014a, b), Rozwałka et al. (2014). Colours of the dots as in the Fig. 32. The red-black dots show the regions, where presence of the species was confirmed

studies. Micrargus apertus is recorded in almost all of the seasons (British Arachnology Society 2017), with the highest abundance from May to October (Arachnologische Gesellschaft 2017; Czech Society of Arachnology 2017), while M. georgescuae was recorded mostly from April to October (Czech Society of Arachnology 2017), similar to our study. One of our 

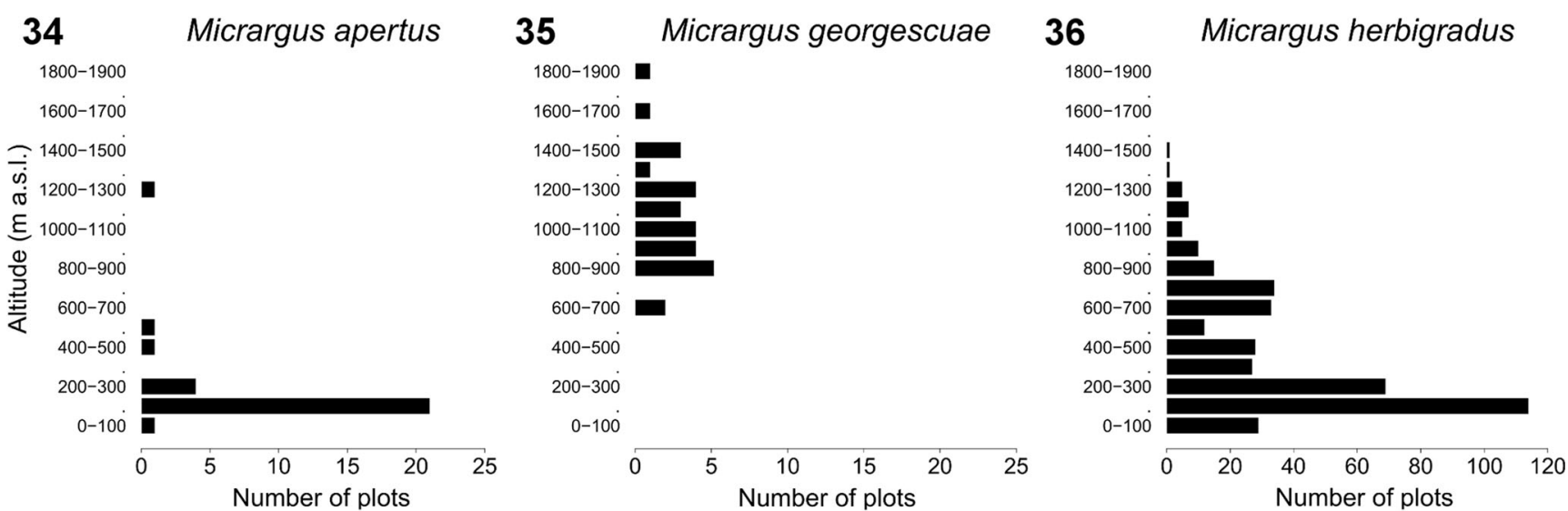

Figs 34-36 Altitudinal distribution of the species from the Micrargus herbigradus-group in Poland. Total number of plots: M. herbigradus - 390, M. apertus -29 , M. georgescuae -28

records of M. georgescuae comes from pitfall traps left for the duration of winter, from October to April (Online Resource 1: Tables S2, S3). Some species with winter activity of adults may be detected by leaving the traps beneath the snow cover. The adults of
M. herbigradus can be found all year round, with a peak between May and July (Arachnologische Gesellschaft 2017; British Arachnological Society 2017; Czech Society of Arachnology 2017). In selected studies - some of which we had to exclude from the analysis - the authors
Figs 37-42 Number of forested or open plots with representatives of the Micrargus herbigradusgroup in Poland and affinity of these species towards habitats of different moisture. Number of plots: M. herbigradus -362 , M. apertus -28 , M. georgescuae - 28 (habitat type);

M. herbigradus -373 , M. apertus - 29, M. georgescuae - 28 (moisture)

\section{7}

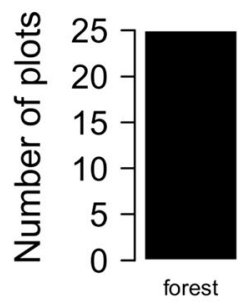

38

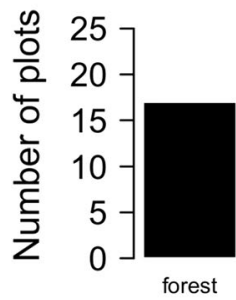

39
Micrargus apertus

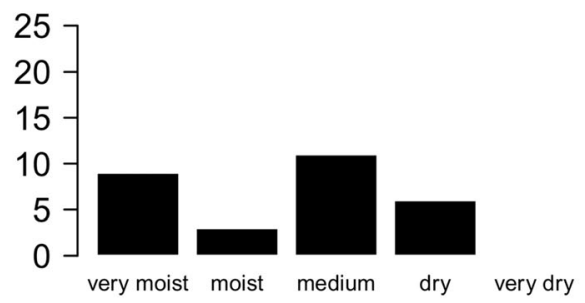

Micrargus georgescuae

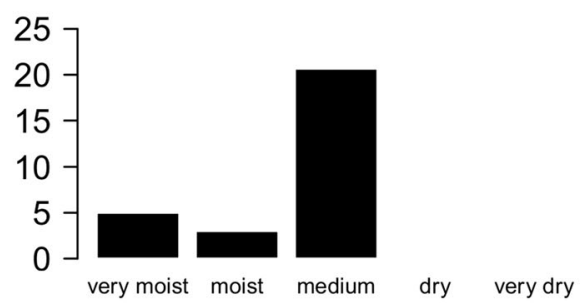

Micrargus herbigradus

42

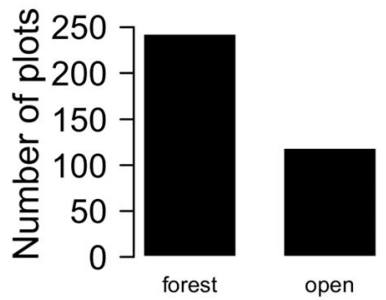

Habitat type

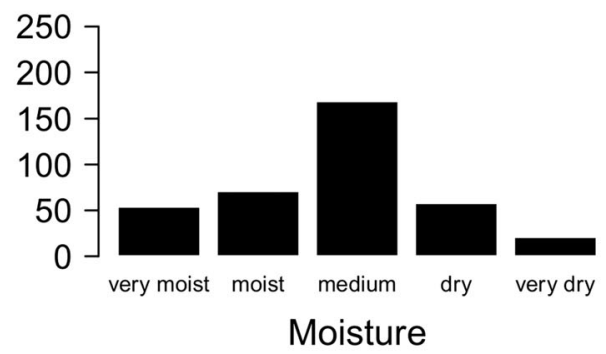


Figs 43-45 Temporal distribution of records within the Micrargus herbigradus-group in Poland. Number of records:

M. herbigradus $-365, M$. apertus -31, M. georgescuae - 55 (males and females as separate records)
43

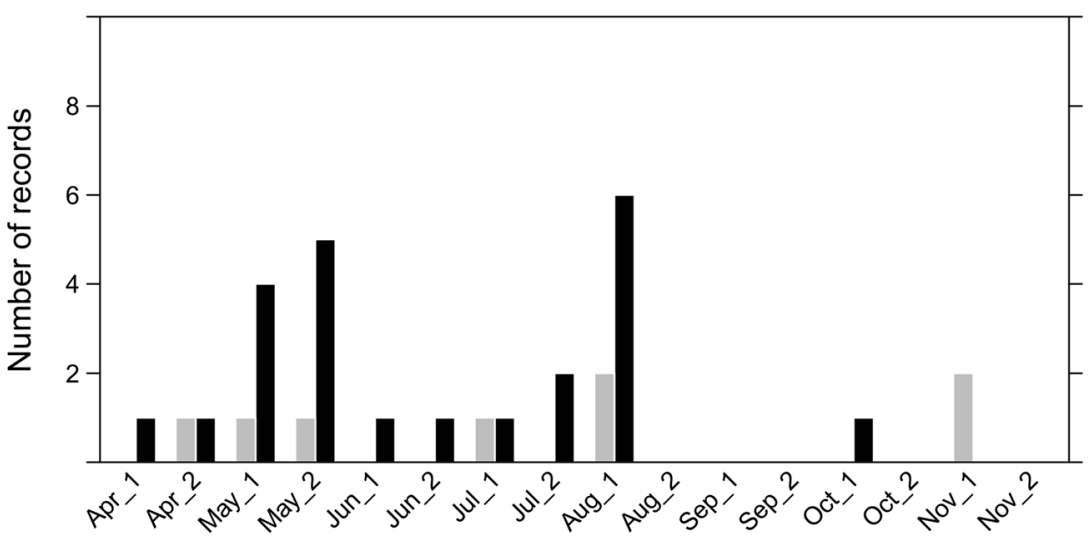

44

Micrargus georgescuae

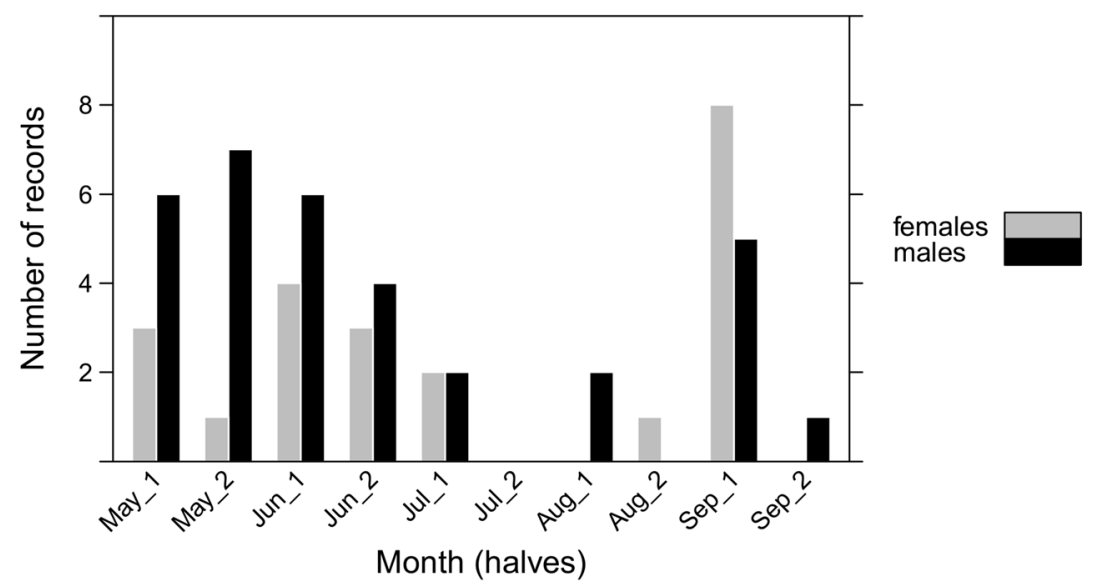

45

Micrargus herbigradus

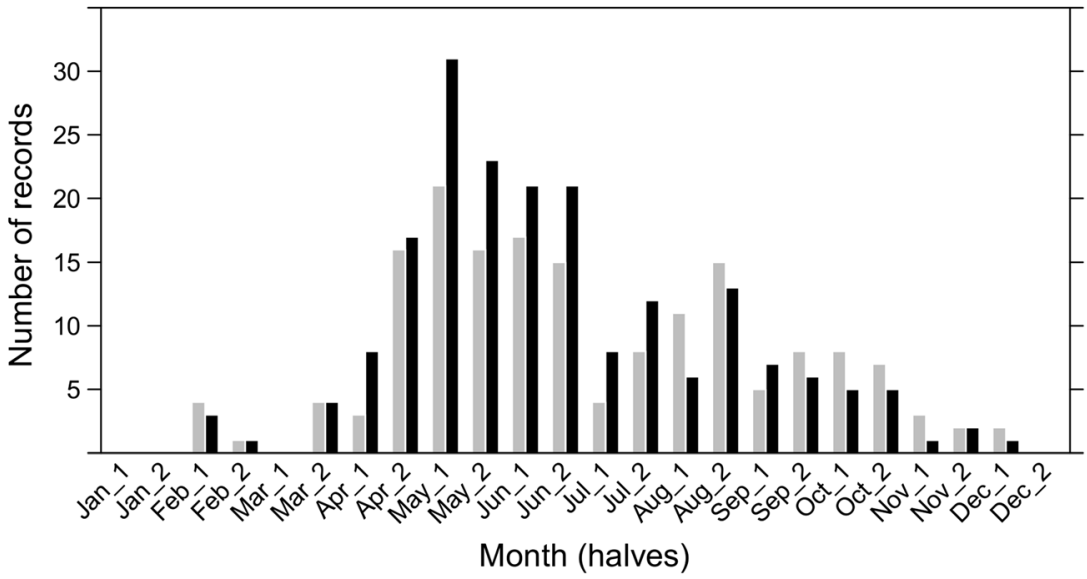

observed two abundance peaks in late spring and in autumn (Starega 2000, 2003a), or recorded considerable winter activity of this Micrargus species (Woźny 1992).

Our review on the Micrargus herbigradus-species group is one of the first works of its kind that deals with the spider fauna of Poland. It shows that there is still a need to clarify data on spider distribution and ecology, and to revisit published works. The knowledge of spiders is dispersed in various articles, predominantly only of local importance, and reviewing their information will 
enable more thorough analysis and allow them to be considered within a broader European context.

Acknowledgments We would like to thank the numerous institutions responsible for nature protection in Poland for giving us their permission and support for our research. We give thanks to all of the researchers that supplied us with material or who gave their assistance during field work. Special thanks to Marzena Stańska and Janusz Kupryjanowicz for providing the specimens for the analysis and to Charles Haddad for proofreading the text.

Conflict of interest The authors declare that they have no conflict of interest.

Open Access This article is distributed under the terms of the Creative Commons Attribution 4.0 International License (http:// creativecommons.org/licenses/by/4.0/), which permits unrestricted use, distribution, and reproduction in any medium, provided you give appropriate credit to the original author(s) and the source, provide a link to the Creative Commons license, and indicate if changes were made.

\section{References}

Arachnologische Gesellschaft (2017) Atlas of the European Arachnids. http://atlas.arages.de. Accessed 30 June 2017

Baldy K (2002) Rola zgrupowań pająków w zooindykacji szczelin piaskowcowych Gór Stołowych. Parki nar Rez Przyr 21:451-469

Baldy K, Woźny M (1998) Stan zbadania araneofauny na terenie Parku Narodowego Gór Stołowych. Szczeliniec 2:89-96

Bednarz S, Czajka M (1966) Drugie stanowisko pająka Saloca diceros (Cambridge) (Micryphantidae) w Polsce. Przegl Zool 10:397-398

British Arachnological Society (2017) Spider and Harvestman Recording Scheme website. http://srs.britishspiders.org.uk/. Accessed 30 June 2017

Buchar J, Růžička V (2002) Catalogue of spiders of the Czech Republic. Peres Publishers, Praha

Chyży I, Staręga W (1997) Pająki (Araneae) rezerwatu Antoniuk. Parki nar Rez Przyr 16:27-39

Cichocki W, Rozwałka R (2013) Pająi rezerwatu torfowiskowego „Bór na Czerwonem”. Chrońmy Przyr Ojcz 69:41-54

Czajka M (1976) Nowe stanowiska rzadkich gatunków pająków (Aranei) w Polsce. Zesz Przyr Opol TPN 16:19-130

Czajka M, Domin L (1993) Pająki (Aranei) okolic Ruszowa w Borach Dolnośląskich. Zesz Przyr Opol TPN 29:7-30

Czajka M, Goos M (1976) Pająki (Aranei) pól buraków cukrowych w Pawłowicach Wielkich koło Wrocławia. Pol Pis Ent 46:179-185

Czajka M, Kornalewicz W (1982) Pająki (Aranei) kilku biotopów Doliny Odry. Zesz Przyr Opol TPN 21:133-140

Czech Society of Arachnology (2017) Online Atlas, Araneae. https:// www.arachnology.cz/rad/araneae-1.html. Accessed 30 June 2017

Dahl F (1902) Über Stufenfänge echter Spinnen im Riesengebirge. Sitzber Ges naturf Freu Berlin 1902:185-203

Deltshev K, Kajak A (1974) Analysis of a sheep pasture ecosystem in the Pieniny Mountains (the Carpathians). XVI. Effect of pasture management on the number and biomass of spiders (Araneae) in two climatic regions (the Pieniny and the Srednia Góra mountains). Ekol pol 22:693-710

Dziabaszewski A (1974) Z badań nad pająkami (Aranei) Wielkopolski II. Bad Fizjogr Pol Zach, ser. C-Zool 27:53-67
Dziabaszewski A (1989) Uwagi faunistyczne o rzadszych gatunkach pająków (Aranei) z Poznania (z listą 302 stwierdzonych gatunków). Bad Fizjogr Pol Zach, ser. C-Zool 38:5-21

Dziabaszewski A (1991) Pająki grądowego rezerwatu „Jakubowo” ze szczegółowym uwzględnieniem fenologii oraz struktury zgrupowań Aranei. Prace Kom Biol Pozn TPN 73:35-55

Dziabaszewski A, Dziabaszewska J, Ciołek J, Jankowski A (1989) Pająki (Aranei) grąóow Wielkopolski. Bad Fizjogr Pol Zach, ser. C-Zool 38:35-42

Entling W, Schmidt MH, Bacher S, Brandl R, Nentwig W (2007) Niche properties of Central European spiders: shading, moisture and the evolution of the habitat niche. Glob Ecol Biogeogr 16:440-448. https://doi.org/10.1111/j.1466-8238.2006.00305.x

Franc V (2002) Contribution to the knowledge on spiders (Araneae) of the Vel'ká Fatra Mts. Matthias Belivs Univ Proc, Suppl 2:155-163

Gajdoš P, Moscaliuc LA, Rozwałka R (2014) Red list of spiders (Araneae) of the Carpathian Mts. In: Kadlečík J (ed) Carpathian Red List of forest habitats and species. Carpathian list of invasive alien species (draft). The State Nature Conservancy of the Slovak Republic, Banská Bystrica, pp 118-135

Georgescu M (1971) Quelques considerations sur le genre Micrargus (Dahl) en Roumanie. Trav Institut Spéol "Émile Racovitza" 10: 235-244

Hajdamowicz I, Stańska M, Król A, Hirler A, Nicewicz Ł (2016) Rzadkie i zagrożone gatunki pająków w zbożach w województwie lubelskim. Kulon 21:49-61

Hänggi A, Stöckli E, Nentwig W (1995) Lebensräume mitteleuropäischer Spinnen. Charakterisierung der Lebensräume der häufigsten Spinnenarten Mitteleuropas und der mit diesen vergesellschafteten Arten. Misc Faun Helv 4, Neuchâtel

Hirna A, Gnelitsa V, Zhukovets E (2016) A checklist of the spiders (Araneae) of the Chornohora Mountain massif (Ukrainian Carpathians). Arachnol Mitt / Arachnology Letters 51:16-38. https://doi.org/10.5431/aramit5104

Höfer H, Blick T, Muster C, Paulsch D (2010) Artenvielfalt und Diversität der Spinnen (Araneae) auf einem beweideten Allgäuer Grasberg (Alpe Einödsberg) und unbeweideten Vergleichsstandorten im Naturschutzgebiet Allgäuer Hochalpen. Andrias 18:53-78

Jędryczkowski W, Staręga W (1980) Bezkręgowce lądowe (Isopoda, Diplopoda, Aranei, Opiliones) rezerwatu kserotermicznego „Kulin”. Fragm faun 25:179-197

Kajak A (1960) Zmiany liczebności pająków na kilku łąkach. Ekol pol, ser B 8:199-228

Kajak A, Oleszczuk M (2004) Effect of shelterbelts on adjoining cultivated fields: patrolling intensity of carabid beetles (Carabidae) and spiders (Araneae). Pol J Ecol 52:155-172

Krzyżanowska E (1982) Pająki (Aranei) skarpy wiślanej w Warszawie. Fragm faun 27:59-66

Krzyżanowska E, Dziabaszewski A, Jackowska B, Staręa W (1981) Spiders (Arachnoidea, Aranei) of Warsaw and Mazovia. Memorabilia Zool 34:87-110

Kulczyński W (1876) Dodatek do fauny pajęczaków Galicyi. Spraw Kom Fiz 10:41-67

Kulczyński W (1881) Wykaz pająków Tatr, Babiéj Góry i Karpat szlązkich $\mathrm{z}$ uwzględnieniem pionowego rozsiedlenia pająków $\mathrm{w}$ Galicyi zachodniéj. Spraw Kom Fiz 15:248-322

Kupryjanowicz J (2003) Spiders (Araneae) of open habitats in the Biebrza National Park, Poland. Fragm faun 46:209-237

Kupryjanowicz J (2005) Pająki (Araneae) Biebrzańskiego Parku Narodowego. In: Dyrcz A, Werpachowski C (eds) Przyroda Biebrzańskiego Parku Narodowego. Biebrzański Park Narodowy, Osowiec-Twierdza, pp 275-299

Kupryjanowicz J (2008) Pająki, Araneae. In: Bogdanowicz W, Chudzicka E, Pilipiuk I, Skibińska E (eds) Fauna Polski. 
Charakterystyka i wykaz gatunków. Muzeum i Instytut Zoologii PAN, Warszawa, pp 223-239

Kůrka A, Vaněk J (2001) Spiders (Araneae) of shaded and non-shaded sites in the tundra of the western Giant Mountains (Czech Republic). Opera Corcontica 38:219-233

Kůrka A, Vaněk J (2009) Fauna pavouků (Araneae) jižního svahu Sněžky (Krkonoše). Opera Corcontica 46:149-158

Łęgowski D (1995) Antropogeniczne przeobrażenia zgrupowań pająków (Aranei) w ekosystemach borów sosnowych. In: Szujecki A (ed) Antropogeniczne przeobrażenia epigeicznej i glebowej entomofauny borów sosnowych. SGGW, Warszawa, pp 381-460

Łęgowski D (2001) Waloryzacja Puszczy Białowieskiej metodą zooindykacyjną na podstawie pająków (Aranei). In: Szujecki A (ed) Próba szacunkowej waloryzacji lasów w Puszczy Białowieskiej metodą zooindykacyjną. SGGW, Warszawa, pp 207-233

Łęowski D (2006) Spiders (Aranei). In: Szujecki A (ed) Zooindicationbased monitoring of anthropogenic transformations in Białowieża Primeval Forest. SGGW, Warszawa, pp 247-291

Łuczak J (1960) Rozmieszczenie piętrowe pająków w lesie. Ekol pol, ser B 6:39-50

Łuczak J, Woźny M (1999) Effect of spruce forest decline on spider communities of Karkonosze Mts. Pol J Ecol 41:429-447

Majkus Z (2006) Arachnofauna rašelinišst' NPR Praděd. Čas Slez Zem Muz. Opava (A) 55:239-248

Materna J, Vaněk J, Kůrka A, Vonička P (2010) Epigeičtí pavouci (Araneae), sekáči (Opiliones) a střevlíci (Coleoptera: Carabidae) vybraných rostlinných společenstev krkonošské a skandinávské tundry. Opera Corcontica 47:187-210

Maurer R, Walter JE (1980) Für die Schweiz neue und bemerkenswerte Spinnen (Araneae). Mitt Schweiz entomol Ges 53:157-162

Millidge AF (1976) Re-examination of the erigonine spiders "Micrargus herbigradus" and "Pocadicnemis pumila" (Araneae: Linyphiidae). Bull Brit Arach Soc 3:145-155

Muster C, Leipold D (2001) Drei für Deutschland neue Zwergspinnen aus dem bayerischen Alpenraum (Araneae: Linyphiidae, Erigoninae). Arachnol Mitt 22:1-10. https://doi.org/10.5431/aramit2201

Nentwig W, Blick T, Gloor D, Hänggi A, Kropf C (2017) Spiders of Europe, version 01.10.15 www.araneae.unibe.ch. Accessed 30 June 2017

Nowicki M (1874) Dodatek do fauny pajęczaków Galicyi. Spraw Kom Fiz 8:2-11

Oleszczuk M (2010) Refugia śródpolne, jako siedliska rzadziej spotykanych i zagrożonych gatunków pająków (Araneae) w Polsce. Chrońmy Przyr Ojcz 66:361-375

Pilawski S (1962) Wstępne badania pająków w Karkonoskim Parku Narodowym. Acta Univ Wrat 3. Prace zool 1:181-188

Pilawski S (1965) O kilkunastu gatunkach pająków złowionych w Sudetach Sląskich nowych dla fauny Dolnego Śląska i Polski. Przegl Zool 9:254-265

Pilawski S (1966a) Wstępne badania pająków w Górach Świętokrzyskich. Acta Univ Wrat 51. Prace zool 2:1-70

Pilawski S (1966b) Wstępne badania pająków okolic Kudowy Zdroju (woj. wrocławskie). Przegl Zool 10:19-66

Pilawski S (1967) Materiały do znajomości pająków (Araneae) Wzgórz Trzebnickich. Przegl Zool 11:391-404

Pilawski S (1970) Przyczynek do ekologii niektórych gatunków pająków (Aranei) z Dolnego Śląska. Przegl Zool 14:47-61

Prószyński J, Staręa W (1971) Pająki - Aranei. Katalog Fauny Polski 33, PWN, Warszawa

Puszkar T (1981) Zmiany wybranych elementów zoocenoz w agroekosystemach poddawanych silnej presji emisji przemysłowych. IUNG Puławy 157:1-79

Rëlys V, Weiss I (1997) Micrargus alpinus sp. n., eine weitere Art der M. herbigradus-Gruppe aus Österreich (Arachnida: Araneae:
Linyphiidae). Rev Suisse Zool 104:491-501. https://doi.org/10. 5962/bhl.part.80007

Rozwałka R (2000) Pająki (Araneae) zespołu Brachypodio-Teucrietum rezerwatu „Stawska Góra”. In: Łętowski J (ed) Walory przyrodnicze Chełmskiego Parku Krajobrazowego i jego najbliższych okolic. Wydawnictwo UMCS, Lublin, pp 109-118

Rozwałka R (2004) Materiały do znajomości pająków (Araneae) Roztocza. Nowy Pam Fizjogr 3:101-116

Rozwałka R (2006a) Pająki (Araneae) Nadwieprzańskiego Parku Krajobrazowego. Nowy Pam Fizjogr 4:55-66

Rozwałka R (2006b) Materiały do poznania pająków (Araneae) Poleskiego Parku Narodowego. Nowy Pam Fizjogr 4:67-82

Rozwałka R (2006c) Pająki (Araneae) stanowiska roślinności kserotermicznej w Żmudzi koło Chełma. Parki nar Rez Przyr 25: $51-68$

Rozwałka R (2007a) Materiały do znajomości pająków (Araneae) Wyżyny Lubelskiej. Nowy Pam Fizjogr 5:145-173

Rozwałka R (2007b) Pajaki (Araneae) Kazimierskiego Parku Krajobrazowego. Parki nar Rez Przyr 26:83-100

Rozwałka R (2008) Wykaz krytyczny pająków (Araneae) Ojcowskiego Parku Narodowego. Parki nar Rez Przyr 27:63-79

Rozwałka R (2009) Pająki (Araneae) Parku Krajobrazowego Lasy Janowskie. Nowy Pam Fizjogr 6:45-70

Rozwałka R (2010a) Uzupełnienia i sprostowania informacji o pająkach (Araneae) z Parku Narodowego Gór Stołowych. Przyr Sud 13:99 113

Rozwałka R (2010b) Zbiór pająków (Araneae) Muzeum Górnośląskiego w Bytomiu. Acta ent Sil 18:79-94

Rozwałka R (2010c) Materiały do znajomości pająków Araneae Bieszczadów i Bieszczadzkiego Parku Narodowego. Rocz Bieszcz 18:167-177

Rozwałka R (2012) Materiały do znajomości pająków Araneae Bieszczadzkiego Parku Narodowego. Rocz Bieszcz 20:156-195

Rozwałka R (2014a) Materiały do znajomości pająków Araneae Beskidu Wschodniego. Rocz Bieszcz 22:239-350

Rozwałka R (2014b) Pająki (Araneae) Magurskiego Parku Narodowego. Rocz Bieszcz 22:351-370

Rozwałka R, Juszczyński P (2009) Pająki (Araneae) dwu nalessowych stanowisk kserotermicznych w okolicach Lublina. Nowy Pam Fizjogr 6:87-106

Rozwałka R, Renn K, Sienkiewicz P (2014) Pająi (Araneae) i kosarze (Opiliones) Lednickiego Parku Krajobrazowego (I). Przegl Przyr 25:42-63

Růžička V, Hajer J (2000) Pavouci (Araneae) mokřadů Lučiny u Tisé (Boh. bor. occ.) Sbor Okres muz Most, řada př́rodověd 22:13-18

Sanocka-Wołoszyn E (1964) Uwagi nad rozmieszczeniem i ekologią pająków (Araneae) z jaskiń Gór Świętokrzyskich. Seminarium speleologiczne I Ogólnopolskiego Zjazdu Badaczy Krasu, Kielce: $73-86$

Sanocka-Wołoszynowa E (1981) Badania pajęczaków (Aranei, Opiliones, Pseudoscorpionida) Wyżyny KrakowskoCzestochowskiej. Acta Univ Wrat 548. Prace Zool 11:1-92

Schenkel E (1929) Spinnen vom Riesengebirge, gesammelt von E. Nielsen. Entomol Medd 16:335-338

Sielicki M, Staręga W (1996) Pająki (Araneae) ekotonu ols-łąka w okolicach Białegostoku. Fragm faun 39:169-177

Stańska M (2005) Pająki (Araneae) jako element monitoringu ekologicznego w wybranych środowisk leśnych Puszczy Białowieskiej. Leś Pr Bad 1:65-79

Stańska M (2007) Rare and threatened spider species (Araneae) in selected types of deciduous forests in the Białowieża Forest. Nat Conserv 64:13-29

Stańska M, Hajdamowicz I, Żabka M (2002) Epigeic spiders of alder swamp forests in Eastern Poland. In: Toft S, Scharff N (eds) Proceedings of the 19th European Colloquium of Arachnology. Aarhus University Press, Aarhus, pp 191-197 
Stańska M, Łydkowska M (2008) Pająki (Araneae) dąbrowy świetlistej w rezerwacie Dębniak. Leś Pr Bad 69:309-320

Staręa W (1966) Przyczynek do poznania fauny pająków (Aranei) Polski. Fragm faun 13:175-186

Starega W (1971) Pajaki (Aranei) Bieszczadów. Fragm faun 17:53-126

Staręga W (1972) Nowe dla fauny Polski i rzadsze gatunki pająków (Aranei), z opisem Lepthyphantes milleri sp. n. Fragm faun 18:5598

Staręga W (1974) Materiały do znajomości rozmieszczenia pająków (Aranei) w Polsce. Fragm faun 19:395-420

Starega W (1976) Pajaki (Aranei) Pienin. Fragm faun 21:233-330

Staręga W (1978) Materiały do znajomości rozmieszczenia pająków (Aranei) w Polsce, III-VII. Fragm faun 23:259-302

Staręga W (1984) Materiały do znajomości rozmieszczenia pająków (Aranei) w Polsce, VIII-X. Fragm faun 28:79-136

Staręga W (1988) Pająki (Aranei) Gór Świętokrzyskich. Fragm faun 31: 185-359

Starega W (1989) Spiders (Aranei) of moist meadows on the Mazovian Lowland. Memorabilia Zool 43:37-60

Staręga W (1995) Pająki Puszczy Knyszyńskiej. In: Czerwiński A (ed) Puszcza Knyszyńska, Monografia przyrodnicza. Zespół Parków Krajobrazowych w Supraślu, Supraśl, pp 279-298

Starega W (1996a) Spinnen (Araneae) aus der Borkenheide und anderen Lokalitäten der Masurischen Seenplatte. Fragm faun 39:287-311

Staręga W (1996b) Spinnen (Araneae) von oberschlesischen Abraumhalden des Steinkohlebergbaus. Fragm faun 39:329-344

Staręga W (2000) Spinnen aus Roztocze und anliegenden Gebieten. Fragm faun 43:59-89

Staręa W (2003a) Pająki (Araneae) Puszczy Knyszyńskiej. Nowy Pam Fizjogr 1:95-206

Starega W (2003b) Pajaki z Nadbużańskiego Parku Krajobrazowego. Parki nar Rez Przyr 22:531-541

Staręga W, Kupryjanowicz J (1996) Beitrag zur Kenntnis der Spinnen (Araneae) des Gorce-Gebirges. Fragm faun 39:313-328

Starega W, Kupryjanowicz J (2001) Subclassis (podgromada): Araneae pająki. In: Gutowski JM, Jaroszewicz B (eds) Katalog fauny Puszczy Białowieskiej, IBL Warszawa, pp 55-64

Staręga W, Stankiewicz A (1996) Beitrag zur Spinnenfauna einiger Moore Nordostpolens. Fragm faun 39:345-361

Svatoň J, Kovalčík R (2006) Present state of knowledge of araneo-fauna in the Tatras National Park. Oecol Mont 15:1-14

Svatoň J, Thomka V, Gajdoš P (2003) Pavúky (Araneae). In: Mašán P, Svatoň J (eds) Pavúkovce Národného Parku Poloniny. Štátna ochrana prírody SR, Banská Bystrica a S-NP Poloniny, Snina, Humenné, pp 21-113
Szymkowiak P, Górski G (2004) Spider communities in the contact zone between open areas and spruce forest in the Karkonosze National Park. Opera Corcontica 41:309-315

Szymkowiak P, Woźny M, Błażejczyk M (1999) A comparison of the species composition of spider communities over sixty years in the vicinity of Krotoszyn. Fragm faun 42:29-40

Thaler K (1978) Über wenig bekannte Zwergspinnen aus den Alpen-V (Arachnida: Aranei, Erigonidae). Beitr Entomol 28:183-200

Tomek T (1988) The breeding biology of the Dunnock Prunella modularis modularis (Linnaeus, 1758) in the Ojców National Park (South Poland). Acta Zool Crac 31:115-166

Urák I, Samu F (2008) Contribution to the spider fauna of the Mohos peat bog from Transylvania, with some new data for Romania. NorthWest J Zool 4:50-60

Wojtaczka M, Woźny M (1993) Pająki (Aranei) podłoża Gór Złotych. Acta Univ Wrat 977. Prace Zool 26:39-64

Wolak M (2002) The spider fauna of balks. In: Toft S, Scharff N (eds) Proceedings of the 19th European Colloquium of Arachnology. Aarhus University Press, Aarhus, pp 229-326

Wolak M (2004) The significance of unmanaged "island" habitats for epigeic spiders in a uniform agricultural landscape. In: Samu F, Szinetár C (eds) Proceedings of the 20th European Colloquium of Arachnology. Budapest - Szombathely, pp 327-336

Woźny M (1975a) Pajaki (Aranei) południowej Opolszczyzny. Prace OTPN. Wydział III Nauk Przyrodniczych 50:1-100

Woźny M (1975b) Nowe dane do znajomości fauny pająków (Aranei) Gór Opawskich. Zesz Przyr Opol TPN 14-15:209-218

Woźny M (1976) Niektóre dane o kilku rzadkich pająkach (Aranei) dla fauny Polski. Zesz Przyr Opol TPN 16:131-136

Woźny M (1985) Pająki (Aranei) Wału Trzebnickiego. Fragm faun 29: $39-76$

Woźny M (1992) Wpływ wilgotności podłoża na zgrupowania pająków oraz dynamika liczebności gatunków dominujących borów sosnowych Wzgórz Ostrzeszowskich. Acta Univ Wrat 1124. Prace Zool 23:25-82

Woźny M (1996) Pająki (Aranei). In: Jahn A, Kozłowski S, Pulina M (eds) Masyw Śnieżnika, zmiany w środowisku przyrodniczym. Polska Agencja Ekologiczna S.A, Warszawa, pp 244-249

Woźny M, Czajka M, Pilawski S, Bednarz S (1988) Pająki (Araneae) Polskich Sudetów, Acta Univ Wrat 972. Prace Zool 19:53-128

Woźny M, Szymkowiak P (2000) Epigeic spiders of the pastures of northern Wielkopolska. Arachnol Mitt 20:1-25. https://doi.org/10. 5431/aramit2001 